\title{
IZOKINETINIŲ IR TRADICINIŲ JĖGOS TRENIRUOČIŲ ITAKA MOTERŲ BLAUZDOS LENKIAMŲJŲ RAUMENŲ FUNKCINEI BŪKLEI
}

\author{
Jurga Indriūnienè $\dot{1}^{1,2}$, Alvydas Juocevičius ${ }^{1,2}$, Ieva Eglė Jamontaite் $\dot{e}^{1,2}$, Inga Muntianaitė ${ }^{1}$ \\ ${ }^{1}$ Vilniaus universiteto Medicinos fakulteto Reabilitacijos, fizinès ir sporto medicinos katedra, \\ ${ }^{2}$ Vilniaus universiteto ligoninès Santariškiu kliniku Reabilitacijos, fizinès ir sporto medicinos \\ centras
}

Raktažodžiai: izokinetinè treniruotè, raumenų jèga, raumenų ištvermè

\section{Santrauka}

Tyrimo tikslas - įvertinti moterų blauzdos lenkiamujų raumenų jègos ir ištvermès rodiklių pokyčius po skirtingų treniruočių programų. Tyrime dalyvavo 100 atsitiktinès atrankos būdu atrinktų $18-22$ metų amžiaus moterų. Tiriamosios suskirstytos i kontrolinę $(n=50)$, pirmą $(n=25)$ ir antrą $(n=25)$ grupę. Kontrolinès grupès moterys stebètos tiriamuoju periodu, neitraukiant jų i i treniruočių programą. Pirma grupè atliko tradicinių jègos pratimų programą, antra grupé - izokinetinių treniruočių programą blauzdos tiesiamiesiems ir lenkiamiesiems raumenims lavinti. Visos moterys ištirtos tyrimo pradžioje ir pabaigoje. Tyrimo metu nustatyta, kad tiek tradiciniu jëgos pratimų, tiek izokinetinių treniruočių programa padidino moterų blauzdos lenkiamųjų raumenų jègą $(p<0,05)$ palyginus su kontroline grupe. Antroje tiriamujų grupeje, po izokinetinių treniruočių programos, blauzdos lenkiamujų raumenų jèga padidejjo 16,64 proc. nedominuojančioje ir 18,50 proc. dominuojančioje kojoje $(\mathrm{p}<0,05)$. Pirmos grupès tiriamosioms, atlikusioms tradicinių jègos pratimu programą, 9 proc. padidejjo dominuojančios kojos raumenų jèga $(p<0,05)$. Izokinetinès treniruotès taip pat padidino blauzdos lenkiamųjų raumenų ištvermę: nedominuojančioje kojoje 39,77 proc., dominuojančioje - 33,52 $(\mathrm{p}<0,05)$. Pirmos grupès tiriamujų, atlikusių tradicinių jègos pratimų programą, dominuojančios kojos raumenų ištvermè padidèjo 9,50 proc. $(\mathrm{p}<0,05)$. Kontrolinès grupès moterų nedominuojančios kojos ištvermès rodiklis stebimuo- ju periodu sumažèjo. Tyrimo rezultatai atskleide, kad izokinetinè treniruotè buvo efektyvesnè nei tradicinių jëgos pratimų programa ir reikšmingiau padidino blauzdos lenkiamujuc raumenu jègos ir ištvermès rodiklius. Po izokinetinių treniruočių blauzdos lenkiamujų raumenų jèga padidejo 18,50 proc., ištvermè - 39,77 proc.

\section{Ivadas}

Moters sveikata lemia vaikų, šeimos, taigi, ir visuomenès sveikatą [1]. Deja, dažnai jaunos moterys neskiria pakankamai demesio sveikai elgsenai: menkai fiziškai aktyvios, nesveikai maitinasi, rūko, vartoja svaigiuosius gèrimus, išgyvena dažnus stresus $[2,3]$. Dèl to vis daugiau jaunų moterų turi antsvorị, yra nutukusios, blogejja jų fizinis pajègumas, greitumas, vikrumas ir raumenų funkcinè būklè [4].

Nors apatinių galūnių raumenų funkcinẻ būklè nėra specifinis ar tiesioginis sveikatos rodiklis, tačiau gera kojų raumenų tarpusavio koordinacija, jèga ir ištvermè leidžia išlaikyti judèjimo funkcijas kasdieniniame gyvenime bei aktyvioje fizinejje veikloje [5, 6]. Apatinių galūnių raumenų grupių jëgos asimetrija gali lemti laikysenos, eisenos sutrikimus, padidinti degeneracinių pakitimų bei atramos judamojo aparato traumų atsiradimo riziką $[7,8]$. Moterų absoliuti jèga ịvairiose raumenų grupèse pradeda anksčiau mažèti ir visais amžiaus tarpsniais yra mažesnè nei vyrų. Todèl labai svarbu laiku nustatyti moterų raumenų funkcinès būklès pokyčius ir tinkamai parinkti priemones, padedančias atstatyti raumenų jẻgą, ištvermę ir tarpusavio koordinaciją [9].

Kasdien atliekami fiziniai pratimai padeda išvengti neigiamų raumenų funkcijos pokyčių. Tačiau vis dar nèra bendros nuomonės, kokia pratimų programa yra efektyviausia 
siekiant padidinti raumenų jègą, ištvermę ir raumenų grupių tarpusavio koordinaciją.

Darbo tikslas: i̇vertinti moterų blauzdos lenkiamuju raumenų jègos ir ištvermès rodiklių pokyčius po skirtingų treniruočių programų.

\section{Tyrimo medžiaga ir metodai}

Tyrimas atliktas 2009 - 2013 metais Vilniaus universiteto Medicinos fakulteto Reabilitacijos, fizinès ir sporto medicinos katedroje, Vilniaus universiteto ligoninès Santariškių klinikų Reabilitacijos, fizinès ir sporto medicinos centro Ambulatorinès reabilitacijos skyriuje. Tyrime dalyvavo 100 atsitiktinès atrankos būdu atrinktų $18-22$ metu amžiaus studenčių (amžiaus vidurkis - 20,56 $\pm 1,40 \mathrm{~m}$.).

Tyrime dalyvavo sveikos, profesionaliai nesportuojančios moterys, kurių neįtraukimo ị tyrimą kriterijai buvo: kelio sąnario nestabilumas, traumos, ligos ar operacijos,

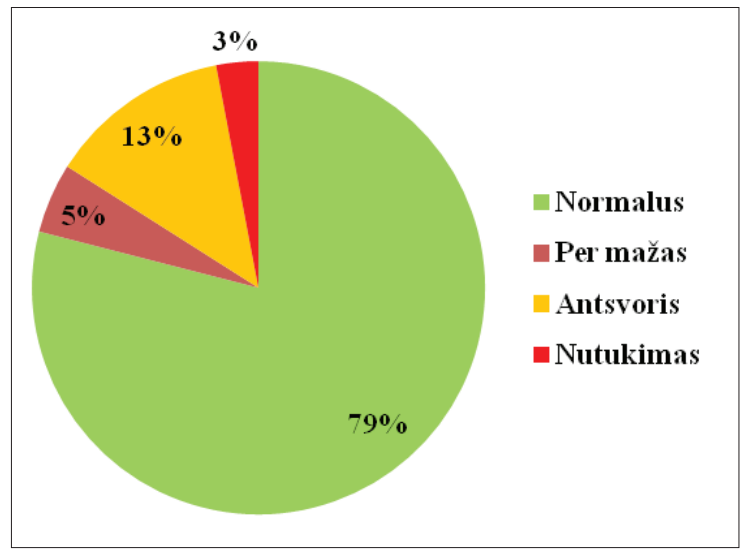

1 pav. Moterų pasiskirstymas pagal kūno masės indeksą nesuaugę apatinių galūnių lūžiai, nekontroliuojama hipertenzija, epilepsija, nëštumas, antikoaguliantu vartojimas, širdies ir kraujagyslių sistemos ligos, kvėpavimo sistemos ligos, fibromialgija.

Studentès pagal atsitiktini metodą suskirstytos ị kontrolinę $(\mathrm{n}=50)$, pirmą $(\mathrm{n}=25)$ ir antrą $(\mathrm{n}=25)$ grupę. Kontrolinès grupès moterys stebètos tiriamuoju periodu, neittraukiant jų $\mathfrak{i}$ treniruočių programą. Pirma grupé atliko tradicinių jègos pratimu programą, antra grupè - izokinetinių treniruočių programą blauzdos tiesiamiesiems ir lenkiamiesiems raumenims lavinti. Visos moterys ištirtos tyrimo pradžioje ir pabaigoje.

Tyrimo metu moterų fizinis aktyvumas įvertintas taikant Tarptautinio fizinio aktyvumo klausimyno sutrumpintą formą. Ivvertinti tiriamujų fizinio išsivystymo rodikliai: ūgis $(\mathrm{cm})$, kūno masè $(\mathrm{kg})$, kūno masès indeksas $\left(\mathrm{kg} / \mathrm{m}^{2}\right)$ - apskaičiuotas kūno masę kilogramais padalijus iš ūgio metrais, pakelto kvadratu. Siekiant įvertinti blauzdos tiesiamujų ir lenkiamujų raumenų funkcinę būklę atliktas testas naudojant izokinetini dinamometrą „Biodex MultiJoint System 4 PRO“. Testo metu moterys atliko 5 judesius $60 \%$ sek, bei 20 judesių $180 \%$ sek kampiniu greičiu. Tarp skirtingu greičių - 60 sekundžių pertrauka. 60 \% sek kampinis greitis naudotas siekiant įvertinti sprogstamają raumenų jègą (ją atspindintis rodiklis - jẻgos momentas, išreikštas $\mathrm{Nm}$ ) bei blauzdos lenkiamujų ir tiesiamujų raumenų jègos momento santykị (išreikštas \%). 180\% sek. kampinis greitis naudotas siekiant ịvertinti raumenų ištvermę (ją atspindintis rodiklis - bendras raumenų darbas, išreikštas J). Pradžioje testas atliktas su dominuojančia koja, tada tie patys judesiai pakartoti su kita koja.

Pirmos grupès tiriamosios 3 ménesius, 2 kartus per savaitę (iš viso 26 užsièmimai) atliko tradicinių jègos pratimų programą, kurios metu taikyti atviros kinetinès grandinès pratimai blauzdos tiesiamiesiems ir lenkiamiesiems raumenims lavinti, palaipsniui didinant pakartojimų skaičių, bei pasipriešinimo svorị. Antros grupés tiriamosios 3 ménesius, 2 kartus per savaitę (26 užsièmimai) atliko izokinetines treniruotes, naudodamos izokinetini dinamometra „Biodex Multi-Joint System 4 PRO“. Treniruotès protokolą sudare kelio tiesimo - lenkimo judesiai koncentriniu režimu $60-180 \%$ sek 


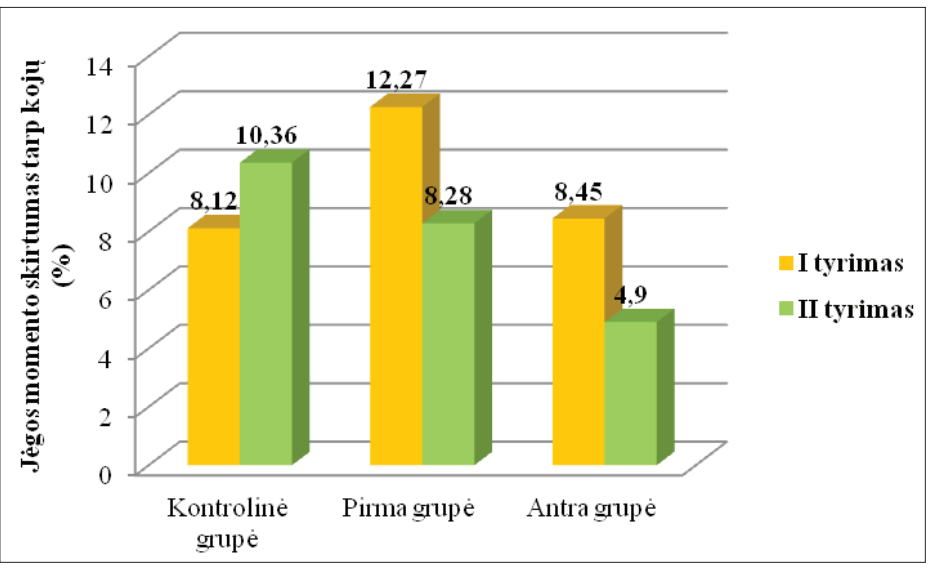

2 pav. Moterų dominuojančios ir nedominuojančios kojos blauzdos lenkiamųjų raumenų jègos momento skirtumas (\%)

2 lentelè. Moterų blauzdos lenkiamųjų ir tiesiamųjų raumenų jègos momento santykis (\%) I ir II tyrimo metu

$M$-vidurkis; SN-standartinis nuokrypis; $n$-tiriamuju skaičius; $p$ - Stjudent'o t-testo kriterijus nepriklausomoms imtims; $p^{*}$-Stjudent'o t-testo kriterijus priklausomoms imtims

\begin{tabular}{|c|c|c|c|c|c|c|}
\hline \multirow{2}{*}{ Rodiklis } & \multirow{2}{*}{$\begin{array}{c}\begin{array}{c}\text { Kontrolinè } \\
\text { grupe } \\
(\mathrm{n}=50)\end{array} \\
\mathrm{M} \pm \mathrm{SN}\end{array}$} & \multirow{2}{*}{$\begin{array}{l}\begin{array}{c}\text { Pirma } \\
\text { grupe } \\
(\mathrm{n}=25)\end{array} \\
\mathrm{M} \pm \mathrm{SN} \\
\end{array}$} & \multirow{2}{*}{$\begin{array}{c}\begin{array}{c}\text { Antra } \\
\text { grupe } \\
(\mathrm{n}=25)\end{array} \\
\mathrm{M} \pm \mathrm{SN}\end{array}$} & \multicolumn{3}{|c|}{$\mathrm{p}$ tarp grupiu } \\
\hline & & & & I - II & $\begin{array}{c}\text { I ir } \\
\text { kontr. }\end{array}$ & $\begin{array}{c}\text { II ir } \\
\text { kontr. }\end{array}$ \\
\hline \multicolumn{7}{|c|}{ Nedominuojanti koja } \\
\hline I tyrimas & $52,10 \pm 8,60$ & $56,44 \pm 9,77$ & $53,86 \pm 9,25$ & 0,318 & 0,053 & 0,425 \\
\hline II tyrimas & $52,06 \pm 8,82$ & $56,07 \pm 8,82$ & $61,26 \pm 7,09$ & 0,032 & 0,055 & 0,000 \\
\hline Pokytis (\%) & $-0,08$ & $-0,66$ & 13,74 & & & \\
\hline $\mathrm{p}^{*}$ & 0,974 & 0,753 & 0,000 & & & \\
\hline \multicolumn{7}{|c|}{ Dominuojanti koja } \\
\hline I tyrimas & $52,55 \pm 10,11$ & $54,75 \pm 10,57$ & $51,40 \pm 8,23$ & 0,231 & 0,362 & 0,634 \\
\hline II tyrimas & $52,40 \pm 9,86$ & $57,54 \pm 8,24$ & $60,60 \pm 6,66$ & 0,219 & 0,018 & 0,000 \\
\hline Pokytis (\%) & $-0,29$ & 5,10 & 17,90 & & & \\
\hline $\mathrm{p}^{*}$ & 0,848 & 0,053 & 0,000 & & & \\
\hline
\end{tabular}

3 lentelė. Moterų šlaunies lenkiamųjų raumenų bendras darbas (J) I ir II tyrimo metu

$M$ - vidurkis; $S N$ - standartinis nuokrypis; $n$ - tiriamuju skaičius; $p$ - Stjudent'o t-testo kriterijus nepriklausomoms imtims; $p^{*}$ - Stjudent'o t-testo kriterijus priklausomoms

\begin{tabular}{|c|c|c|c|c|c|c|}
\hline \multirow{2}{*}{ Rodiklis } & \multirow{2}{*}{$\begin{array}{c}\begin{array}{c}\text { Kontroli- } \\
\text { nè grupé } \\
(\mathrm{n}=50)\end{array} \\
\mathrm{M} \pm \mathrm{SN}\end{array}$} & \multirow{2}{*}{$\begin{array}{c}\begin{array}{c}\text { Pirma } \\
\text { grupe } \\
(\mathrm{n}=25)\end{array} \\
\mathrm{M} \pm \mathrm{SN}\end{array}$} & \multirow{2}{*}{$\begin{array}{c}\begin{array}{c}\text { Antra } \\
\text { grupe } \\
(\mathrm{n}=25)\end{array} \\
\mathrm{M} \pm \mathrm{SN}\end{array}$} & \multicolumn{3}{|c|}{$\mathrm{p}$ tarp grupių } \\
\hline & & & & I - II & $\begin{array}{c}\text { I ir } \\
\text { kontr. }\end{array}$ & $\begin{array}{l}\text { II ir } \\
\text { kontr. }\end{array}$ \\
\hline \multicolumn{7}{|c|}{ Nedominuojanti koja } \\
\hline I tyrimas & $\begin{array}{c}677,75 \\
\pm 212,02\end{array}$ & $\begin{array}{c}798,69 \\
\pm 247,46\end{array}$ & $\begin{array}{c}601,19 \\
\pm 187,99\end{array}$ & 0,064 & 0,073 & 0,151 \\
\hline II tyrimas & $\begin{array}{c}639,94 \\
\pm 202,07\end{array}$ & $\begin{array}{c}835,06 \\
\pm 230,35\end{array}$ & $\begin{array}{c}840,26 \\
\pm 204,40\end{array}$ & 0,930 & 0,000 & 0,000 \\
\hline Pokytis (\%) & $-5,58$ & 4,55 & 39,77 & & & \\
\hline $\mathrm{p}^{*}$ & 0,001 & 0,291 & 0,000 & & & \\
\hline \multicolumn{7}{|c|}{ Dominuojanti koja } \\
\hline I tyrimas & $\begin{array}{c}690,28 \\
\pm 231,65 \\
\end{array}$ & $\begin{array}{c}789,86 \\
\pm 226,28 \\
\end{array}$ & $\begin{array}{c}631,03 \\
\pm 176,18 \\
\end{array}$ & 0,091 & 0,065 & 0,270 \\
\hline II tyrimas & $\begin{array}{c}656,78 \\
\pm 202,19\end{array}$ & $\begin{array}{c}864,91 \\
\pm 195,63\end{array}$ & $\begin{array}{c}842,56 \\
\pm 206,49\end{array}$ & 0,696 & 0,000 & 0,000 \\
\hline Pokytis (\%) & $-4,85$ & 9,50 & 33,52 & & & \\
\hline $\mathrm{p}^{*}$ & 0,054 & 0,021 & 0,000 & & & \\
\hline
\end{tabular}

kampiniu greičiu. Abiejų grupių tiriamosios prieš treniruotę ir po jos atliko 5 minučiu apšilimą/atvèsimą veloergometru (50 W, 60 apsuk./min). Vieno užsièmimo trukmé palaipsniui didinta nuo 30 iki $45 \mathrm{~min}$.

Statistinè duomenų analizè atlikta naudojant SPSS 15.0 statistinès analizès paketą. Tolydiesiems kintamiesiems vertinti apskaičiuotas matematinis vidurkis $(\mathrm{M})$ ir standartinis nuokrypis (SN). Dvieju nepriklausomų imčių vidurkiams palyginti taikytas Stjudent'o (t) kriterijus nepriklausomoms imtims. Dviejų priklausomų imčių vidurkiai lyginti Stjudent'o (t) poriniu kriterijumi. Duomenys statistiškai reikšmingi, kai $\mathrm{p}<0,05$ (lentelèse žymi pilkas fonas).

\section{Rezultatai}

Ivertinę apklausos metu gautus duomenis apie fizini aktyvumą nustateme, kad 33 proc. tiriamujų užsièmé labai intensyvia ir vidutiniškai intensyvia veikla bent 150 minučių per savaitę, o tai, remiantis Pasaulio sveikatos organizacijos (2010) rekomendacijomis, atitiko normą [10]. Tiriamujų kūno masès indekso (KMI) vidurkis buvo 21,59 $\pm 2,80$ $\mathrm{kg} / \mathrm{m}^{2} .5$ proc. moterų KMI buvo per mažas, 16 proc. tiriamujų turèjo antsvori ar buvo nutukusios (1 pav.) [11].

İvertinę blauzdos lenkiamujų raumenų funkcinès būklès rodiklių pokytị nustateme, kad tiek tradicinių jëgos pratimų programa, tiek izokinetinių treniruočių programa padidino moterų blauzdos lenkiamųjų raumenų jègą $(\mathrm{p}<0,05)$ palyginus su kontroline grupe. Tačiau izokinetinių treniruočiu programos poveikis buvo ženklus abiem kojoms, kai tradicinių treniruočių programą atlikusioms moterims - tik dominuojančiai kojai (1 lentelè).

10 proc. skirtumas tarp kairès ir dešinès galūnès raumenų jègos yra nereikšmingas, tačiau didesnis nei 10 proc. disbalansas yra kelio sąnario traumos rizikos veiksnys [12]. Jégos momento skirtumo tarp koju (\%) analizè parodè, kad geriausių rezultatų suvienodinant dominuojančios ir nedominuojančios kojos rezultatus sekèsi pasiekti II grupès tiriamosioms - iki $\mathrm{M}=4,90(\mathrm{p}=0,022)$, ir šis rezultatas statistiškai reikšmingai skyrèsi nuo kontrolinès grupès $(M=10,36 ; p=0,003)$ ( 2 pav.).

Blauzdos lenkiamujų ir tiesiamujų raumenų jègos santykis naudojamas siekiant įvertinti kelio sąnario stabilumą, raumenų funkcines galimybes ir tarpusavio balansą $[13,14]$. Esant 60 \% sek kampi- 


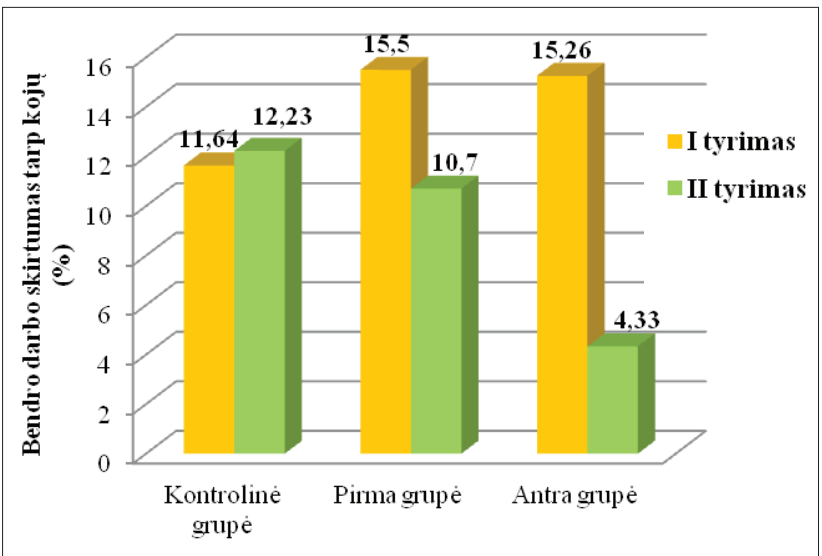

3 pav. Moterų dominuojančios ir nedominuojančios kojos blauzdos lenkiamųų raumenų bendro darbo skirtumas (\%)

niam greičiui, minimalus ir siektinas santykis yra $60-62$ proc. [15].

Blauzdos lenkiamujų ir tiesiamųjų raumenų jègos momento santykio kitimas pateikiamas 2 lentelèje. Ją analizuojant matyti, kad antroje moteru grupeje tiek dominuojančioje, tiek nedominuojančioje kojoje buvo pastebimas santykio padidejimas (13 - 17 proc.) ir šiais rezultatais jos skyrèsi nuo kontrolinės grupės tiriamuju $(\mathrm{p}<0,05)$. Nedominuojančioje kojoje statistiškai reikšmingas skirtumas gautas ir lyginant su pirmos grupés tiriamosiomis $(\mathrm{p}$ $=0,032$ ). Tuo tarpu pirmos grupès moterų rezultatai 5,10 proc. pagerejjo vertinant tik dominuojančios kojos blauzdos lenkiamujų ir tiesiamųjų raumenų jègos momento santyki $(\mathrm{p}=0,018)$.

3 lenteleje pateikti rezultatai rodo, kad šlaunies lenkiamujų raumenų ištvermès rodiklis statistiškai reikšmingai padidèjo abiejose besitreniravusių moterų grupėse, palyginus su kontroline grupe. Izokinetinès treniruotès padidino tiek nedominuojančios, tiek dominuojančios kojos ištvermę (atitinkamai 39,77 ir 33,52 proc.) ( $\mathrm{p}<0,001)$, tuo tarpu tradicinių jẻgos pratimų programa buvo efektyvi tik vertinant dominuojančios kojos rezultatus (padidèjo 9,50 proc.) $(\mathrm{p}=0,021)$.

Vertinant bendro darbo skirtumo tarp kojų pokyti matomas net 71,63 proc. skirtumo sumažèjimas (nuo $M=15,26$ iki $\mathrm{M}=4,33$ ) antroje moteru grupeje ir tuo jos skyrèsi nuo kontrolinės grupès, kur skirtumas buvo $\mathrm{M}=12,23$ ( $\mathrm{p}=$ $0,001)$, ir nuo pirmos grupès moterų, kur skirtumas buvo $\mathrm{M}$ $=10,70(\mathrm{p}=0,024)(3$ pav. $)$.

\section{Rezultatu aptarimas}

Žmogaus raumenų jèga yra didžiausia 20 - 30 metų laikotarpiu ir palaipsniui mažèja iki 50 metu amžiaus. At- siranda neuroraumeninių pokyčių, dèl kurių sumažèja raumenų jèga, pablogejja motorika, atsiranda funkcinių sutrikimų, didèja neigalumo atsiradimo rizika. Kasdien atliekami fiziniai pratimai padeda išvengti raumenų pokyčių [16]. Jauniems, kelio sąnario pažeidimų neturintiems asmenims kelio tiesiamujų ir lenkiamujjų raumenų maksimalus sukimo momentas turi padidèti 15 - 20 proc., kad pokytis būtų laikomas ženkliu ir statistiškai reikšmingu [17]. Mūsų tyrimo metu po izokinetinių treniruočiu programos sveikų moterų lenkiamujų raumenu jèga padidèjo 16,64 proc. nedominuojančioje ir 18,50 proc. dominuojančioje kojoje (p $<0,05)$. L. Miller ir bendraautoriai (2009) ištyrè $18-26$ metų amžiaus moteris, kurioms taikè vienos, nedominuojančios kojos izokinetines treniruotes, trukusias 20 savaičių. Po šių treniruočių jų tiriamujų maksimalus sukimo momentas blauzdos lenkiamuosiuose ir tiesiamuosiuose raumenyse padidejjo $15-21$ proc. [18]. Panašius rezultatus gavo J. Cannon ir F. Marino (2010) - 7,1 - 27,8 proc. [19]. Mūsų tyrimo metu izokinetinių treniruočių programa taip pat padidino moterų blauzdos lenkiamujų raumenų ištvermę tiek nedominuojančioje, tiek dominuojančioje kojoje, atitinkamai 39,77 ir 33,52 proc. ( $p<0,001)$. Tačiau tyrimų, kuriuose būtų įvertintas raumenų ištvermès pokytis po izokinetinių treniruočių, vis dar nepakanka, kadangi dauguma tyrèjų didesnị dèmesị skiria raumenų jëgos parametrams vertinti ir interpretuoti.

L. Lustosa ir bendraautoriai (2011) atliko tyrimą, kurio metu sieke ịvertinti tradicinių jègos pratimų programos, kuri yra taikoma klinikineje praktikoje, efektyvumą. Tyrèjai nustatè, kad po tradicinių jëgos ir ištvermès pratimų programos sveikų moterų raumenų galia padidèjo 1,8 proc., darbas išreikštas kūno svoriui - 2,69 proc., tačiau šie rezultatai buvo statistiškai nereikšmingi. Tuo tarpu raumenų jègos pokyčio nebuvo pastebèta [20]. Mūsų tiriamosioms, atlikusioms tradicinių jẻgos pratimų programą, dominuojančios kojos blauzdos lenkiamujų raumenų jèga padidejjo 9 proc. $(\mathrm{p}<0,05)$, o nedominuojančios kojos 2,30 proc. pokyčiai buvo nereikšmingi. Taip pat šios treniruotès 9,50 proc. padidino blauzdos lenkiamujų raumenų ištvermę ( $p$ $<0,05)$.

Galime teigti, kad izokinetinių treniruočių programa, taikoma siekiant pagerinti sveikų moterų raumenų funkcinę būklę, buvo efektyvesnè nei tradicinių jègos pratimų programa. Šių treniruočių metu raumenys optimaliai apkraunami dinaminėmis sąlygomis, o judesio greitis yra pastovus. Tokio pobūdžio judesys užtikrina maksimalų raumenų susitraukimą per visą pratimą kiekvienam sąnarinio judesio laipsniui, sukelia minimalų skausmą po krūvio ir apsaugo sąnarị nuo pažeidimų [21]. Todèl izokinetinio pasipriešinimo treniruote yra saugi, gerai toleruojama ir 
gali būti taikoma jaunų moterų raumenų funkcinei būklei pagerinti.

\section{Išvados}

Izokinetinè treniruotė buvo efektyvesnè nei tradiciniu jègos pratimų programa ir reikšmingiau padidino blauzdos lenkiamujų raumenų jègos ir ištvermès rodiklius. Po izokinetinių treniruočių blauzdos lenkiamujų raumenų jèga padidèjo 18,50 proc., ištvermè - 39,77 proc.

\section{Literatūra}

1. Drąsutienė G.S., Tutkuvienė J., Zakarevičienė J. ir kt. Nėščiųjų antropometrinių rodiklių, medžiagų apykaitos ir naujagimių fizinès būklès pokyčiai per pastaruosius dešimtmečius. Medicina, 2007; 43(1):10-26.

2. Leyk D, Witzki A, Gorges W. et al. Körperliche Leistungsfähigkeit, Körpermaße und Risikofaktoren von 18-35-jährigen Soldaten: Ergebnisse der Evaluierungsstudie zum Basis-Fitness-Test (BFT). Wehrmed Mschr 2010;54:278-82.

3. Leyk D, Ruther T, Witzki A, Sievert A, Moedl A. et al. Physical fitness, weight, smoking, and exercise patterns in young adults. Dtsch Arztebl Int 2012;109(44):737-45.

4. Stephens MB, Cochran C, Hall JM, Olsen C.Physical fitness during medical school: a 4-year study at the uniformed services university. Fam Med 2012;44(10):694-7.

5. Markovic G. Does plyometric training improve vertical jump height? A meta-analytical review. Br J Sports Med 2007;41(6):349-355.

http://dx.doi.org/10.1136/bjsm.2007.035113

6. Risberg MA, Holm I. The long-term effect of 2 postoperative rehabilitation programs after anterior cruciate ligament reconstruction: a randomized controlled clinical trial with 2 years of follow-up. Am J Sports Med 2009;37(10):1958-66. http://dx.doi.org/10.1177/0363546509335196

7. Trudelle-Jackson E, Ferro E, Morrow JR Jr. clinical implications for muscle strength differences in women of different age and racial groups: the win study. J Womens Health Phys Therap 2011;35(1):11-18. http://dx.doi.org/10.1097/JWH.0b013e318212570c

8. Andrade Mdos S, De Lira CA, Koffes Fde C, Mascarin NC, Benedito-Silva AA, Da Silva AC. Isokinetic hamstrings-toquadriceps peak torque ratio: the influence of sport modality, gender, and angular velocity. J Sports Sci 2012;30(6):547-53. http://dx.doi.org/10.1080/02640414.2011.644249

9. Akbari M, Mousavikhatir R. Changes in the muscle strength and functional performance of healthy women with aging. MJIRI 2012;26(3):125-131.

10. World Health Organisation. Global recommendations on physical activity for health 2010 .

11. World Health Organisation. Global Database on Body Mass Index 2006.
12. Biodex multi-joint system III pro-operations manual. New York, NY: Biodex Medical System Inc.; 1999.

13. Wong DP, Wong SHS. Physiological profile of Asian elite youth soccer players. J Strength Cond Res 2009;23:1383-1390. http://dx.doi.org/10.1519/JSC.0b013e3181a4f074

14. Kong PW, Burns SF. Bilateral difference in hamstrings to quadriceps ratio in healthy males and females. Phys Ther Sport 2010;11:12-17.

http://dx.doi.org/10.1016/j.ptsp.2009.09.004

15. Andrade Mdos S, De Lira CA, Koffes Fde C, Mascarin NC, Benedito-Silva AA, Da Silva AC. Isokinetic hamstrings-toquadriceps peak torque ratio: the influence of sport modality, gender, and angular velocity. J Sports Sci 2012;30(6):547-53. http://dx.doi.org/10.1080/02640414.2011.644249

16. Boff SR. A fibra muscular e fatores que interferem no seu fenotipo. Acta Fisiatrica 2008;15(2):111-6.

17. Sole G, Hamrén J, Milosavljevic S, Nicholson H, Sullivan SJ. Test-retest reliability of isokinetic knee extension and flexion. Arch Phys Med Rehabil 2007;88(5):626-31. http://dx.doi.org/10.1016/j.apmr.2007.02.006

18. Miller LE, Nickols-Richardson SM, Wooten DF et al. Isokinetic resistance training increases tibial bending stiffness in young women. Clasif Tissue Int 2009;84(6):446-52. http://dx.doi.org/10.1007/s00223-009-9247-5

19. Cannon J, Marino FE. Early-phase neuromuscular adaptations to high- and low-volume resistance training in untrained young and older women. J Sports Sci 2010;28(14):1505-14. http://dx.doi.org/10.1080/02640414.2010.517544

20. Lustosa LP, Silva JP, Coelho FM, Pereira DS et al. Impact of resistance exercise program on funktional capacity and muscular strength of knee extensor in pre-frail community-dwelling older women: a randomized crossover trial. Rev Bras Fisioter 2011;15(4):318-24.

http://dx.doi.org/10.1590/S1413-35552011000400010

21. Costa RA, de Oliveira LM, Watanabe SH, Jones A, Natour J. Isokinetic assessment of the hip muscles in patients with osteoarthritis of the knee. Clinics 2010; 65(12):1253-1259. http://dx.doi.org/10.1590/S1807-59322010001200006

\section{ISOKINETIC AND TRADITIONAL STRENGTH TRAINING PROGRAM INFLUENCE ON WOMEN'S KNEE FLEXORS FUNCTIONAL STATUS J. Indriūnienė, A. Juocevičius, I. E. Jamontaitė, I. Muntianaitè}

Key words: isokinetic training, muscle strength, muscle eni durance

Summary

Women's absolute strength in various muscular groups starts to decrease earlier and is less than men's during all life stages. That is why it is very important to timely define changes of women's muscle functional status and to choose an effective training proh gram that would help to restore muscle strength, endurance and intercoordination. 
Methods: the research included 100 randomly selected $18-22$ year-old women (mean age - 20,56 $\pm 1,40 \mathrm{y}$ ). Women were randomly subdivided into control $(\mathrm{n}=50)$, first $(\mathrm{n}=25)$, second ( $=25$ ) groups. The women from the control group were observed during the research period without their inclusion into the training program. The first group performed traditional strength exercising program, the second group performed isokinetic training program to improve their knee flexors and extensors status. All the women were evaluated in the beginning and the end of the training program.

Results: both traditional strength exercises and isokinetic training program improved the women's knee flexors' strength in comparison with the control group $(p<0,05)$. In the second group of the studied after isokinetic training program knee flexors' strength increased in $16,64 \%$ in non-dominating leg and $18,50 \%$ in dominating leg $(\mathrm{p}<0,05)$. After traditional strength exercising program of the first group women, there was $9 \%$ increase of dominating leg muscle strength. Isokinetic training also improved knee flexors' endurance: in non-dominating leg $39,77 \%$, in dominating leg $-33,52 \%(p<0,05)$. The dominating leg's muscle endurance of the first group women, who performed traditional strength exercising program, increased in $9,50 \%(\mathrm{p}<0,05)$. During the study, the non-dominating leg endurance index of the control group women decreased.

Conclusions: isokinetic training was more effective than traditional strength exercises and the indexes of knee flexors' strength and endurance increased more significantly. After isokinetic traind ing, muscle strength increased in 18,50 \%, endurance - 39,77\%.

Correspondence to: jurga.indriuniene@mf.vu.lt

Gauta 2016-06-21 